\title{
In-vitro dialysability of iron in green leafy vegetables and seasonal variation of total iron content
}

\author{
Jaanaki Gooneratne* and S. C. Kumarapperuma \\ Food Technology Division, Industrial Technology Institute, Colombo - 7 .
}

Revised: 12 November 2006 ; Accepted: 28 November 2006

\begin{abstract}
Green leafy vegetables are considered a good source of iron in Sri Lankan diets, particularly among populations dependant on plant based diets. The iron status of diets can be improved by including iron rich plant sources and enhancing the bioavailability by cooking/processing.
\end{abstract}

The mean total iron content \pm SD of the green leafy vegetables studied were as follows (expressed as fresh weight, $\mathrm{mg} / 100 \mathrm{~g}$ ): sarana (Trianthema portulacastrum L.): $6.7 \pm 1.5$, rathu thampala (Amaranthus lividis. L.): 13.4 \pm 2.7 ; nivithi (Basella alba L.): 1.3 \pm 0.6 ; kathrumurunga \{Sesbania grandiflora (L.) Poir.\}: 3.2 \pm 0.7 ; mukunuwenna \{Alternanthera sessili (L.)Dc. $\}: 1.8 \pm 0.3$; kankun (Ipomoea aquatica. Forssk. ): $1.9 \pm 0.9$ and gotukola \{Centella asiatica (L). Urban\}: 5.2 \pm 1.6 . The seasonal variation observed was not significant $p>0.05$ over the period of one year. These values indicate that the contribution of iron from green leafy vegetables to the diets is low.

The freshly cooked and dehydrated-cooked samples (hot-air drier at $55^{\circ} \mathrm{C}$ ) were blended with water and subjected to simulated gastro-intestinal digestion procedures, following which the proportion of iron that diffused through a semi permeable membrane (molecular mass cut-off $10 \mathrm{kDa}$ ) determined-cooked as the dialyzable iron. This was quantified spectrophometrically at $535 \mathrm{~nm}$. The dialysable iron extracted from the freshly cooked and dehydrated - cooked green leafy vegetables ranged between 1.5-13.4\% and 3.6-17.6\% respectively. Accordingly the best sources of available iron from green leafy vegetables are sarana, kathrumurunga and rathu thampala.

Key Words: Dialysable iron, green leafy vegetables, iron

\section{INTRODUCTION}

Green leafy vegetables are considered a good source of iron, calcium and B-carotene in Sri Lankan diets, particularly among populations that are largely dependant on plant based diets. Choice of the iron rich plant sources, market availability and improved bioavailability through cooking/ processing are factors that contribute towards improving the iron status of the population.

The bioavailability of iron from plant material is low ${ }^{1}$ as compared to animal sources. It has been demonstrated that $\mathrm{Fe}^{2+}$ is more available than $\mathrm{Fe}^{3+}$. Dietary constituents such as amines, ascorbic acid and citric acid enhance iron availability from the $\operatorname{diet}^{2}$. The absorption of iron from cereals and legumes however, is low due to the presence of inhibitory factors such as phytates ${ }^{3}$ and tannins ${ }^{4}$. Literature reviews show that processing of cereals and legumes using traditional methods or other technologies enhance absorption of iron by destroying inhibitors or through the formation of beneficial complexes between food components and the metal ions, thereby enhancing its iron availability ${ }^{5}$.

The iron available from food materials classified as elemental, soluble, complexed and ions, have been quantified by chemical methods ${ }^{6,7}$. In recent times in-vitro iron dialysability methods have been used for predicting the bioavailability of iron from food sources. This method is in reasonable agreement with human absorption data ${ }^{8}$ and is far more cost effective when compared to in vitrodigestion/Caco-2 cell culture models used to demonstrate iron availability ${ }^{9}$.

This study reports the seasonal variation in the total iron content of seven green leafy vegetables and evaluates their in-vitro availability of iron (as dialysable iron) for indexing the best sources of iron available from the same which are commonly consumed in Sri Lanka. 


\section{METHODS AND MATERIALS}

Materials: Seven green leafy vegetables, locally known as sarana (Trianthema portulacastrum L.), rathu thampala (Amaranthus lividis L.), nivithi (Basella alba L.), kathurumurunga \{Sesbania grandiflora (L.) Poir\}, mukunuwenna (Alternanthera sessili (L.) Dc.), kankun (Ipomoea aquatica Forssk.) and gotukola \{Centella asiatica (L.) Urban. $\}$ were obtained from Piliyandala through a main supplier of green leafy vegetables to the Colombo district during the period of August 2002 to July 2003. Plants were identified at the National Herbarium of Botanical Gardens, Peradeniya. Five representative samples were drawn from a bulk (3000 g) of each green leafy vegetable, at 5-6 day intervals of each month, for quantifying the variability in the total iron content $(n=60)$.

Digestive enzymes and bile salts were purchased from Sigma Chemical Co., (St.Louis, MO, USA). A pepsin digestion mixture was prepared by suspending $16 \mathrm{~g}$ pepsin (P-7000 from porcine stomach mucosa) in $100 \mathrm{~mL} 0.1 \mathrm{M}$ $\mathrm{HCl}$. The pancreatin-bile extract contained $4 \mathrm{~g}$ pancreatin (P-1750, from procine pancreas) and $25 \mathrm{~g}$ bile extract (B-8631, porcine) dissolved in $1 \mathrm{~L}$ of $0.1 \mathrm{M} \mathrm{NaHCO}^{3}$.

All chemicals were of Analar Grade and purchased from BDH, Poole, England. A protein precipitation solution was prepared by mixing $100 \mathrm{~g}$ trichloroacetic acid, $100 \mathrm{~g}$ hydroxylamine and $100 \mathrm{~g}$ of $370 \mathrm{~g} \mathrm{~L} \mathrm{HCl}$ and made up to $1 \mathrm{~L}$. The chromogen solution contained $250 \mathrm{~g}$ of bathophenanthroline sulphate dissolved in $1 \mathrm{~L}$ of $2 \mathrm{M}$ Sodium Acetate. Iron standards, containing 0.1, 0.2, 0.4, 0.8 and $1.6 \mu \mathrm{g} \mathrm{Fe}(\mathrm{II}) \mathrm{mL}^{-1}$ in $10 \mathrm{~g} \mathrm{~L} \mathrm{HCl}$ were used for establishing a calibration curve $\left(\mathrm{R}^{2}=0.9906\right)$. Iron was determined spectophotometrically using a Hach spectrophotometer-Model DR/4000 (Hach Co. Colarado, USA).

Distilled water used in the assay was Milli Q water. Dialysis tubing Spectra (Por 7) with a molecular cut of 10000 Da were obtained from Cole Parmer Instrument Co. Ltd, USA. A Colworth Stomacher Lab-Blender Model 400 (Seaward Medical, London, U.K.) was used for blending the samples. A drier ("Mitchel" Model, Prachitt Brothers Ltd., Carlisle, U.K.) was used for hot-air drying of samples.

Stimulated digestion method: In the determination of dialyzable iron content, freshly purchased green leafy vegetables were washed, shredded and the material was cooked with water (1:5) for $10 \mathrm{~min}$. Dehydrated green leafy vegetables were prepared after washing and drying in a hot-air drier at $55^{\circ} \mathrm{C}$. The dehydrated product was powdered and cooked with water $(1: 10)$ for $10 \mathrm{~min}$.
The cooked samples of both freshly processed and dehydrated powders of all seven green leafy vegetables were homogenized separately and an aliquot of the samples (in triplicate) were subjected to simulated gastrointestinal digestion as described ${ }^{8}$. In the gastric stage, the sample (20 g) was adjusted to $\mathrm{pH} 2.0$ by adding $6 \mathrm{M} \mathrm{HCl}$. Freshly prepared pepsin solution $(5 \mathrm{~g})$ was added and made up to $100 \mathrm{~g}$ with water. The sample was mechanically digested in a stomacher and was incubated at $37^{\circ} \mathrm{C}$, for $2 \mathrm{~h}$ in a shaking water bath. A homogenized pepsin digest $(20 \mathrm{~g})$ was taken in an Erlenmeyer flask and the $\mathrm{pH}$ was adjusted to 7.5 with O. $5 \mathrm{M} \mathrm{NaOH}$ (after determining the titratable acidity). Freshly prepared pancreatin mixture $(5 \mathrm{~g})$ was added. A calculated amount of sodium bicarbonate (after determining the titratable acidity) dissolved in $25 \mathrm{~g}$ of water contained in a semi-permeable membrane (molecular mass cut-off $10 \mathrm{kDa}$ ) was introduced to the flask. The contents of the flask were incubated at $37^{\circ} \mathrm{C}$, for $2 \mathrm{~h}$ in a shaking water bath. The dialyzed bags were rinsed with water, carefully dried and weighed. The contents of each dialysed bag was transferred into acid-washed containers and analysed for its iron content.

The aliquots of the dialysate or standard solution $(10 \mathrm{~mL})$ were pipetted into test tubes and mixed with $5 \mathrm{ml}$ of protein solution. Each tube was covered and kept in a boiling water bath for $10 \mathrm{~min}$. The sample was then centrifuged $(3500 \mathrm{~g} 10$ min). The supernatant $(5 \mathrm{~mL})$ was mixed with $2.5 \mathrm{~mL}$ of chromogen solution and the colour was allowed to develop for $10 \mathrm{~min}$. The amount of dialyzable iron $(\mathrm{mg} / \mathrm{kg})$ was determined spectrophometrically at $535 \mathrm{~nm}$.

The moisture content, total ash and total iron content in all samples were determined according to AOAC methods ${ }^{10}$.

\section{RESULTS}

The moisture content in the green leafy vegetables varied between $76.8-92.8 \%$. The mean total iron content \pm SD of the green leafy vegetables (expressed as fresh weight, $\mathrm{mg}$ / $100 \mathrm{~g}$ ) were as follows: sarana: $6.7 \pm 1.5$, rathu thampala: $13.4 \pm 2.7$; nivithi: $1.3 \pm 0.6$; kathrumurunga: $3.2 \pm 0.7$; mukunuwenna: $1.8 \pm 0.3$; kankun: $1.9 \pm 0.9$ and gotukola: $5.2 \pm 1.6$. The monthly variations $(\mathrm{n}=60)$ in the total iron content in the seven green leafy vegetables were not significantly different $(p>0.05)$. The results are presented in Figure 1 .

The dialyzable iron extracted from the seven green leafy vegetables varied between the plant materials (Table 1). The dialyzable iron extracted from the dehydrated - cooked plant material was higher as compared to that of the freshly cooked leafy vegetables, except for sarana and nivithi. 


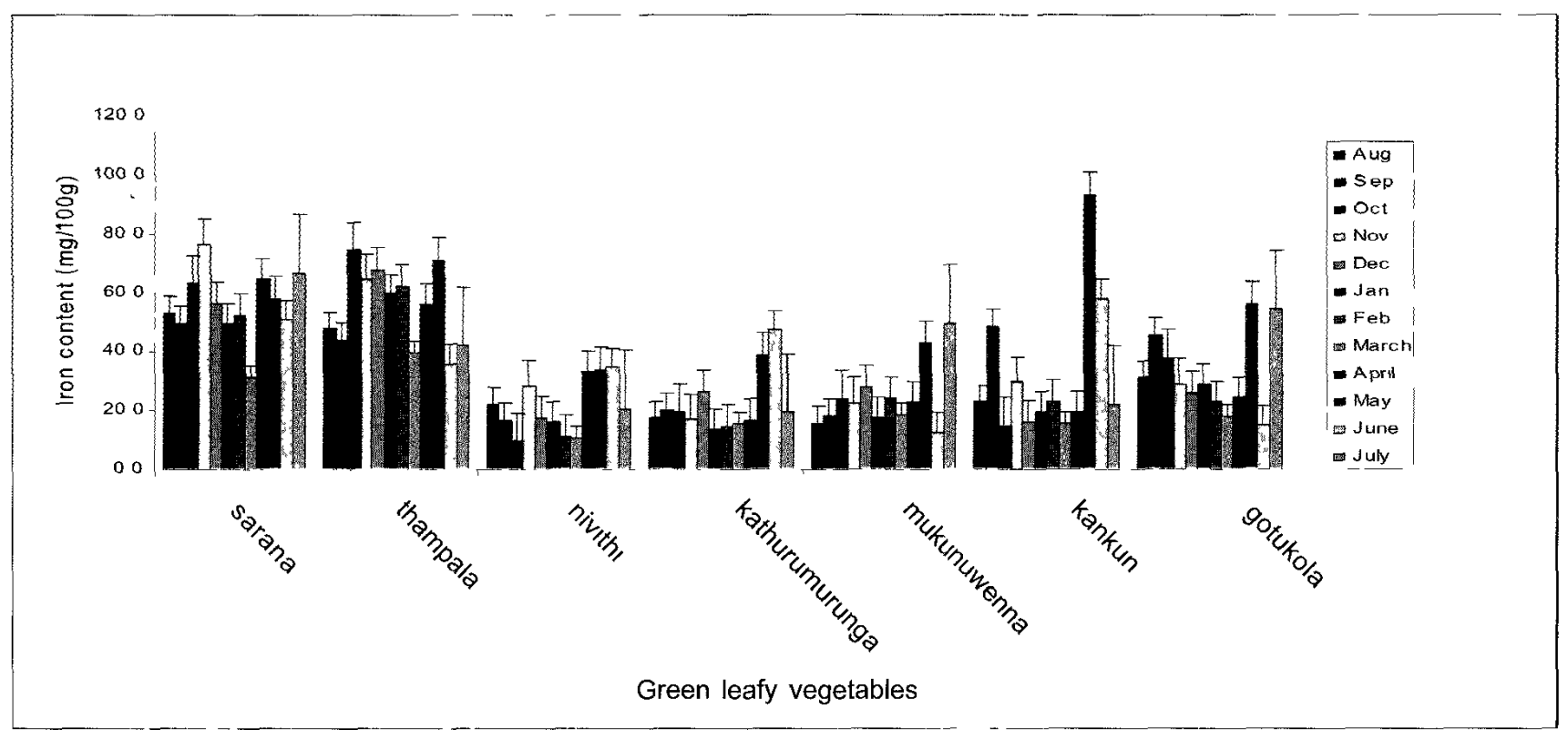

Figure 1: Sedsonal variation in total tron content of green leaty vegetables (dry basis $\pm \mathrm{SE}, \mathrm{n}=60$ )

Table 1: \% dialysable iron extracted from fresh /dehydrated and cooked green leafy vegetables

\begin{tabular}{|c|c|c|c|c|c|c|}
\hline \multirow{2}{*}{$\begin{array}{l}\text { Green leafy } \\
\text { vegetable }\end{array}$} & \multicolumn{3}{|c|}{ Freshly - cooked } & \multicolumn{3}{|c|}{ Dehydrated - cooked } \\
\hline & $\begin{array}{c}\text { \% Morsture } \\
\text { Content }\end{array}$ & $\begin{array}{c}\text { Dialysable iron } \\
\text { (Dry basis, } \mathrm{mg} / \mathrm{kg} \text { ) } \\
\pm \mathrm{SD})\end{array}$ & $\begin{array}{l}\% \text { Dialysable } \\
\text { Iron of total iron }\end{array}$ & $\begin{array}{c}\% \text { Moisture } \\
\text { Content }\end{array}$ & $\begin{array}{c}\text { Dialysable iron } \\
\text { (Dry basis, mg/kg) } \\
\pm \mathrm{SD})\end{array}$ & $\begin{array}{l}\% \text { Dialysable } \\
\text { iron of total iron }\end{array}$ \\
\hline sarana & $87.9 \pm 1.4$ & $38.0 \pm 1.4$ & $6.8 \pm 2.6$ & $1.9 \pm 0.1$ & $244 \pm 1.2$ & $4.3 \pm 0.4$ \\
\hline rathu thampala & $76.8 \pm 17$ & $11.7 \pm 1.3$ & $2.0 \pm 0.6$ & $1.8 \pm 0.2$ & $20.6 \pm 1.4$ & $3.6 \pm 0.6$ \\
\hline nivithı & $92.8 \pm 1.8$ & $23.8 \pm 1.7$ & $13.4 \pm 3.9$ & $2.1 \pm 0.1$ & $7.3 \pm 1.2$ & $4.1 \pm 2.0$ \\
\hline kathurumurunga & $82.3 \pm 2.4$ & $20.4 \pm 1.1$ & $113 \pm 3.9$ & $2.2 \pm 0.1$ & $31.7 \pm 1.4$ & $17.6 \pm 5.8$ \\
\hline mukunuwenna & $91.5 \pm 2.3$ & $165 \pm 0.3$ & $7.8 \pm 0.6$ & $2.1 \pm 0.1$ & $18.0 \pm 0.7$ & $8.5 \pm 1.2$ \\
\hline kankun & $919 \pm 2.3$ & $8.5 \pm 0.3$ & $3.7 \pm 0.6$ & $2.2 \pm 0.1$ & $9.6 \pm 0.4$ & $4.1 \pm 2.6$ \\
\hline gotukola & $81.8 \pm 1.5$ & $4.5 \pm 0.2$ & $1.5 \pm 0.7$ & $2.4 \pm 03$ & $20.5 \pm 0.3$ & $7.0 \pm 2.7$ \\
\hline
\end{tabular}

Values are means of $\pm S D, n=5$

\section{DISCUSSION}

The total iron content of the green leafy vegetables monitored over a period of twelve months was not significantly different $(p>0.05)$. The soll properties such as $\mathrm{pH}$, redox conditions, cation exchange capacity, the activity of microorganisms, soil structure and water content govern the mineral availability to the plant. The availability of iron to the plant depends on its spatiality in the soil. Iron can be present in the soil in different physicochemical forms such as free ionic form, chelates, absorbed onto mineral or organic surfaces, as precipitates, or in lattice structures or as a part of soil biomass.

According to the results the best source of iron was from rathu thampala, which provided $1 / 3$ of the daily requirement of iron per $100 \mathrm{~g}$ fresh weight per 
adult ( $22 \mu \mathrm{g}$ rron), whle sarana and gotukola were good sources of iron providing approximately $1 / 4$ of the Recommended Dally Allowances (RDA) The low ron content of some leafy vegetables could have a negative effect on the population of the Colombo district that consume green leafy vegetables as a source of dietary iron

In this study an attempt was made to quantify the broavarlable iron as dialyzable iron using an in vitro method The dialyzable iron was high in sarana, kathurumurunga and rathu thampala Literature also reports that the iron avallability from green leafy vegetables can be enhanced by the addition of enhancers ${ }^{11}$ such as citric acid, into the food matrix or meal The increase in the dialyzable iron observed in some dehydrated green leafy vegetables may be a result of the processing method

\section{Acknowledgment}

The authors thank JICA for the financial assistance for research grant No JICA/ITI FP 42

\section{References}

1 Layrısse M \& Martınez-Torees C (1971) Food ıron absorption Proceeding of Haematology 7: 137-160

2 Charlton R W, Bothwell TH (1983) Iron absorption Annual Review of Medicine 34: 55-68

3 Hurrel R F, Reddy M B , Berrı J \& Cook J D (2002) Phytate degradation determines the effect of industrial processing and home cooking on tron absorption from cerealbased foods Bitish Journal of Nutriton 88: 117-123

4 Narasingha Rao S \& Prabhavathi T (1982) Tannin content of food commonly consumed in India and its influence on 1onisable iron Journal of Food Science and Agriculture 33: $89-96$

5 Watzke H J (1998) Review on the impact of processing on bio avallability examples of minerals in toods Trends in Food Science and Technology 9: 320327

6 Lee K \& Clydesdale F M (1979) Quantitative determination of the elemental, ferrous, ferric, soluble, and complexed iron in foods Journal of Food Sctence $\mathbf{4 4}$ (2) 549-554

7 Lee K \& Clydesdale F M (1980) Chemical changes of iron in food and drying process Journal of Food Science 45: 711-715

8 Luten J, Helen C, Flynn A, Dael P V, Kastenmayer P, Hurrell R, Deelstra H, Shen L1-Hua, Fairweather-Tait S, Hickson K, Farre R, Schlemmer U, Frohlich W (1996) Interlaboratory trial on the determination of the in vitro iron dialysability from food Journal of Science Food and Agriculture 72: 415-424

9 Glahn R P, Wein E M, Van Campten D R, Miller D D (1996) Caco-2 cell tron uptake from meat and casein digests parallels in vivo studies use of a novel in vitro method for rapid estimation of iron avalability Journal of Nutrition 126: 332-339

10 AOAC (2000) AOAC Method 32 103,32 106\& 32109 In Official Methods of Analysts (Ed W Horwting) $17^{\text {th }}$ Edition Vol II, Association of official Analytical Chemists, Maryland, USA

11 Lee K \& Clydesdale F M (1981) Effect of thermal processing on endogenous and added iron in canned spinach Journal of Food Science 46: 1064-1068 